\title{
Konstruksi Budaya Literasi Dalam Pembelajaran Ekstrakurikuler di SMA Negeri 11 Luwu Utara
}

\author{
Fitra Assyahra ${ }^{1}$ Nurdin $^{2}$ Lukman Ismail $\left.\right|^{3}$ \\ ${ }^{1}$ Program Studi Pendidikan Sosiologi, Universitas Muhammadiyah Makassar \\ Email : fitraassyahra@gmail.com \\ ${ }^{2}$ Program Studi Pendidikan Sosiologi, Universitas Muhammadiyah Makassar \\ Email : nurdin@gmail.com \\ ${ }^{3}$ Program Studi Pendidikan Sosiologi, Universitas Muhammadiyah Makassar \\ Email : lukmanismail@unismuh.ac.id
}

\begin{abstract}
This study explores the construction of literacy culture in extracurricular learning (study on the scientific group of teenagers at SMA Negeri 11 Luwu Utara). The problems studied in this study are: 1. Downloading the Literacy Culture contained in extracurricular learning at SMA Negeri 11 Luwu Utara, 2. Observing the literacy culture in extracurricular learning in the adolescent scientific group (KIR) at SMA Negeri 11 Luwu Utara, 3. Factors what hinders the construction of literacy culture in extracurricular learning at SMA Negeri 11 Luwu Utara. This thesis uses descriptive qualitative research with a phenomenological approach where the phenomenological study tries to find the meaning of experience in life which aims to reveal the construction of literacy culture in extracurricular learning in adolescent scientific groups at SMA Negeri 11 Luwu Utara. The overall informants in this study consisted of thirteen people, the principal, two KIR coaches, library managers, subject teachers and eight students who were members of the youth scientific group. Collecting data in this study using techniques, namely, observation, interviews and documentation. Meanwhile, the data analysis in this study used purposive sampling analysis which started with data analysis of observations, interviews, and documents. The results of this study are that the school has provided facilities that can be used for the learning process, for the literacy cultural activities applied at SMA Negeri 11 Luwu Utara the school has provided a library, reading garden and reading corner room that manages the library with a youth scientific group to manage library, besides that they also invite other students to cultivate a habit of reading during breaks, besides that in terms of extracurricular activities, youth scientific groups are also fostered by supervising teachers to be able to work through a scientific paper, the school also fully supports students who can excel through their writings. There are factors that inhibit students from wanting to participate in reading, namely the lack of interest in reading students towards textbooks produced by free association, the second influence is the rise of online games which increase students prefer to play games rather than reading textbooks again. teacher supervision of students which is the impact of a pandemic that is increasingly prevalent in society, as a result all students are home and learning is carried out by teachers through a brave learning system and this is a factor for students not to want to study or read books, but the school is trying to make students can go to school once a week to pick up textbooks so they can be read and studied at home.
\end{abstract}

Keywords : Construction; Reading Culture; Extracurricular Learning.

Abstrak. Penelitian ini menggali tentang Konstruksi budaya literasi dalam pembelajaran ekstrakurikuler (studi pada kelompok ilmiah remaja di SMA Negeri 11 Luwu utara). Masalah yang dikaji dalam penelitian ini adalah: 1. Bagaimanakah Budaya Literasi yang terdapat dalam pembelajaran ekstrakurikuler di SMA Negeri 11 Luwu Utara, 2. Bagaimanakah konstruksi budaya literasi dalam pembelajaran ekstrakurikuler pada kelompok ilmiah remaja (KIR) di SMA Negeri 11 Luwu Utara, 3. Faktor apakah yang menghambat konstruksi budaya literasi dalam pembelajaran ekstrakurikuler di SMA Negeri 11 Luwu Utara. Skripsi ini menggunakan penelitian kualitatif deskriftif dengan pendekatan fenomenologi dimana dengan Studi fenomenologi mencoba mencari arti dari pengalaman dalam kehidupan yang bertujuan untuk mengungkap Konstruksi budaya literasi dalam pembelajaran ekstrakuriuler pada kelompok ilmiah remaja yang ada di SMA Negeri 11 Luwu Utara. Informan secara keseluruhan dalam penelitian ini terdiri dari tiga belas orang, kepala sekolah, dua orang Pembina KIR, 
pengelola perpustakaan, guru matapelajaran dan delapan orang siswa yang tergabung dalam kelompok ilmiah remaja. Pengumpulan data dalam penelitian ini menggunakan tiga teknik yaitu, observasi, wawancara dan dokumentasi. Sementara analisis data dalam penelitian ini menggunakan analisis purposive sampling yang dimulai dengan analisis data observasi, wawancara, dan dokumen. Hasil dari penelitian ini yaitu sekolah telah memberikan fasilitas yang dapat digunakan untuk proses pembelajaran, teruntuk kegiatan budaya literasi yang di terapakan di SMA Negeri 11 Luwu Utara sekolah telah memfasilitasi berupa perpustakaan, taman baca serta ruang sudut baca yang di kelola olah perpustakaan bekerjasama dengan kelompok ilmiah remaja untuk mengelola perpustakaan, selain itu mereka juga mengajak siswa lain untuk membudayakan membaca di waktu isterahat, selain itu dari segi kegiatan ekstrakurikuler kelompok ilmiah remaja juga dibina oleh guru pembimbing untuk bisa berkarya melalui sebuah tulisan yaitu karya ilmiah sekolah juga mendukung penuh siswa yang bisa berprestasi melalui karya tulisnya. Adapulah yang menjadi faktor penghambat siswa untuk mau ikut membaca yaitu kurangnya minat baca siswa terhadap buku-buku pelajaran yang di akibatkan pergaulan yang semakin bebas, pengaruh yang kedua yaitu maraknya game online yang menambah siswa lebih memilih bermain game ketimbang membaca buku pelajaran di tambah lagi kurangnya pengawasan seorang guru terhadapa siswa diakibatkan dampak pandemik yang semakin marak di masyarakat, akibatnya semua siswa di rumahkan dan pembelajaran yang dilakukan oleh guru melaui system pemmbelajaran daring dan ini yang menjadi faktor siswa juga untuk tidak mau belajar maupun membaca buku, tetapi pihak sekolah mengupayakan agar siswa dapat kesekolah seminggu sekali untuk mengambil buku pelajaran agar dapat di baca dan dipelajari di rumah.

Kata Kunci : Konstruksi; Budaya Baca; Pembelajaran Ekstrakurikuler.

\section{PENDAHULUAN}

Bangsa yang maju tidak hanya di ukur dengan kekeyaan sumber daya alam melainka juga sumber daya manusia yang dimiliki bangsa tersebut, untuk mewujudkan sumber daya manusia yang unggul tentunya terlihat pada budaya yang diproduksi oleh masyarakat-nya. Adapun bentuk budaya yang saat ini berkembang di era global adalah budaya literasi. Budaya Literasi merupakan keterampilan penting dalam hidup. Literasi adalah kemampuan memahami, mengakses dan melakukan sesuatu secara bijak melalui beragam kegiatan, diantaranya melihat, membaca, mendengarkan, menulis dan berbicara. Literasi diartikan sebagai keterampilan dalam memanfaatkan gambar dan bahasa dalam bentuk yang beragam untuk menulis, membaca, berbicara, mendengarkan, berfikir kritis dan menyajikan (Abidin, Mulyati, dan Yunansah, 2017:1).

Dalam PIRLS 2016 International Result In Reading, Indonesia menduduki peringkat ke-45 dari 48 negara peserta dengan skor 428 dari skor rata-rata 500 (IEA, 2015). Sementara itu, uji literasi membaca dalam PISA 2016 menunjukkan peserta didik Indonesia berada pada peringkat ke-64 dengan skor 396 (OECD, 2016). Rendahnya keterampilan tersebut membuktikan bahwa proses pendidikan belum mengembangkan kompetensi dan minat baca peserta didik terhadap pengetahuan (Dirjen Dikdasmen, 2016:2). Permasalahan ini menegaskan bahwa pemerintah memerlukan strategi khusus agar kemampuan membaca peserta didik dapat meningkat dengan mengitegrasikan/menindaklanjuti program sekolah dengan kegiatan dalam keluarga dan masyarakat. Hal ini untuk memastikan kegiatan literasi sekolah sebagai sebuah Gerakan Literasi Sekolah (GLS) agar dampaknya dapat dirasakan di masyarakat.

Gerakan Literasi Sekolah (GLS) adalah usaha yang dilakukan dalam rangka untuk mewujudkan sekolah sebagai organisasi pembelajar yang warga sekolahnya gemar membaca. sejalan dengan pegertian diatas Wiedarti, dkk (2016:2) menyatakan bahwa Gerakan Literasi Sekolah (GLS) merupakan upaya yang menyeluruh melibatkan warga sekolah (guru, peserta didik, orang tua) dan masyarakat, sebagai bagian dari ekosistem pendidikan.

Setiap lembaga pendidikan menginginkan agar setiap siswanya dapat mencapai prestasi yang memuaskan. Prestasi yang dicapai oleh siswa merupakan alat ukur utama untuk mengetahui keberhasilan seorang pendidik. Untuk meningkatkan prestasi belajar siswa, maka diperlukan cara utama sebagai penunjang dalam proses pencapaian tujuan tersebut, dan diantara cara yang harus 
ditempuh adalah melalui pelaksanaan kegiatan ekstrakurikuler yang beragam disetiap lembaga sekolah. Kegiatan ekstrakurikuler merupakan serangkaian program kegiatan belajar mengajar di luar jadwal jam pelajaran terprogram, yang dimaksudkan untuk meningkatkan cakrawala pandang siswa menumbuhkan bakat dan minat serta semangat pengabdian kepada masyarakat. Yang mana ekstrakurikuler tergolong dalam komponen pengembangan diri.' Ekstrakurikuler merupakan suatu kegiatan yang dilakukan oleh para siswa di luar jam pelajaran, biasanya untuk membantu pengembangan peserta didik sesuai dengan kebutuhan, potensi, bakat dan minat melalui kegiatan yang secara khusus diselenggarakan oleh pendidik yang memiliki kemampuan dan kewenangan di sekolah. Adapun kegiatan ekstrakurikuler yang dilaksanakan di sekolah terdapat beberapa jenis. Salah satunya adalah kegiatan karya tulis ilmiah.

Suandi, dkk. (2013: 166) mengungkapkan menulis merupakan serangkaian kegiatan seseorang mengungkapkan gagasan dan menyampaikan informasi melalui bahasa tulis kepada masyarakat pembaca untuk dipahami. Dengan keterampilan menulis seseorang akan dapat melaporkan, memberitahukan, dan meyakinkan orang lain. Pendapat berbeda dikemukakan oleh Keraf (2007:52), bahwa menulis adalah suatu kegiatan yang produktif dan ekspensif. Dengan demikian, menulis merupakan hal yang sangat penting yang perlu dikuasai oleh seseorang. Salah satu keterampilan menulis yang harus dikuasai oleh kaum intelektual adalah menulis karya ilmiah. Pada dasarnya kurikulum sudah mencakup seluruh keterampilan berbahasa, termasuk menulis. Kurikulum tersebut dijabarkan dalam Standar Kompetensi dan Kompetensi Dasar dari jenjang SD sampai SMA. Salah satu Kompetensi Dasar (SK) yang ada dalam kurikulum adalah menulis karya ilmiah yang diberikan di jenjang SMA.

Karya ilmiah adalah hasil atau produk manusia yang biasanya dalam bentuk tulisan atas dasar pengetahuan, sikap, dan cara berpikir ilmiah (Wendra, 2016:2). Itu berarti sudah tentu setiap karya ilmiah harus mengandung kebenaran ilmiah. Kebenaran ilmiah yang dimaksud yakni kebenaran yang tidak hanya didasarkan atas rasio, tetapi juga dibuktikan secara empiris. Menulis karya ilmiah berbeda dengan mengarang biasa. Menulis karya ilmiah membutuhkan metode dan teknik tulisan tertentu sehingga hasil tulisan dapat dipertanggungjawabkan kebenarannya.

Oleh karena itu, tidak semua orang terampil menulis karya ilmiah. Namun, tuntutan pendidikan zaman yang kompetitif seperti saat ini sangat membutuhkan keterampilan menulis karya ilmiah untuk memecahkan berbagai persoalan dengan tepat. Orang yang terampil menulis karya ilmiah akan memiliki nilai lebih dibandingkan dengan orang yang tidak menulis karya ilmiah. nilai lebih yang dimaksud adalah orang yang terampil menulis karya ilmiah mereka akan kaya ilmu pengetahuan, wawasan, bahkan finansial. Mereka terbiasa berpikir sistematis, cermat, tidak sembarangan dalam mengidentifikasi dan memecahkan persoalan.

Keterampilan menulis karya ilmiah tidak hanya bisa didapatkan di dalam kelas atau melalui proses pembelajaran di dalam kelas saja. Namun, keterampilan tersebut bisa didapatkan di luar jam pelajaran. Keterampilan tersebut bisa didapatkan dalam kegiatan ekstrakurikuler. Kegiatan ekstrakurikuler merupakan kegiatan yang dilakukan di luar kelas dan di luar jam pelajaran untuk menumbuhkembangkan potensi sumber daya manusia (SDM) yang dimiliki peserta didik, baik berkaitan dengan aplikasi ilmu pengetahuan yang didapatkan

Salah satu kegiatan ekstrakurikuler yang dapat menambah ilmu pengetahun di bidang menulis karya ilmiah adalah ekstrakurikuler KIR. KIR adalah kelompok remaja yang melakukan serangkaian kegiatan yang menghasilkan karya ilmiah (Susilowarno, 2003:1). Dari pengertian tersebut sudah sangat jelas bahwa keterampilan menulis karya ilmiah tidak hanya bisa didapatkan pada jam pelajaran saja, namun pada kegiatan ekstrakurikuler KIR pun bisa diperoleh ilmu tentang penulisan karya ilmiah. Kegiatan menulis karya ilmiah merupakan suatu kegiatan yang oleh sebagian remaja dianggap sulit, sebab menulis karya ilmiah harus dengan berpikir ilmiah dan harus mengandung kebenaran ilmiah. Hal ini berbeda dengan menulis karya-karya yang lain seperti cerpen dan sejenisnya yang lebih memerhatikan keindahan. Walupun kegiatan menulis karya ilmiah oleh sebagian besar dianggap sulit, bukan berarti tidak dapat dipelajari. Kegiatan ekstrakurikuler KIR merupakan salah satu kegiatan yang bersifat terbuka bagi remaja sebagai peserta didik yang ingin 
mengembangkan kreativitas, ilmu pengetahun, dan teknologi (IPTEK) dan bertujuan agar mampu menanamkan sikap ilmiah, kejujuran dalam memecahkan masalah yang ditemui dengan kepekaan tinggi serta menggunakan metode yang sistematis, objektif, rasional dan berprosedur sehingga akan didapatkan kompetensi untuk mengembangkan diri dalam kehidupan masa kini atau mendatang (Susilowarno 2003:2).

Pada dasarnya kegiatan ekstrakurikuler pengembangan diri atau bakat siswa di dunia sekolah ditujukan untuk menggali dan memotivasi siswa dalam bidang karya tulis ilmiah. Oleh sebab itu, kegiatan ekstrakurikuler harus disesuaikan dengan hobi maupun kondisi siswa. Sedangkan tujuan kegiatan ekstrakurikuler adalah untuk membantu dan meningkatkan bakat juga potensi siswa dalam menulis ilmiah. Sehingga kegiatan ekstrakurikuler karya tulis ilmiah dapat meningkatkan kemampuan berfikir ilmiah dan menuangkannya dalam sebuah tulisan ilmiah.

Dari hasil pemaparan di atas, peneliti memilih fokus penelitian ini di karnakan SMA Negeri 11 Luwu Utara sebagai objek penelitian karena ada hal menarik yang peneliti lihat di dalam kegiatan literasi sekolah. Menurut hasil pengamatan peneliti secara umum, remaja sekarang ini lebih tertarik pada internet dan game daripada membaca buku dan menulis karya ilmiah di karnakan bayaknya reverensi yang mereka dapatkan dari internet ketimbang harus membaca buku. Seringkali sepulang sekolah para remaja menyempatkan diri untuk mampir ke warnet dan menghabiskan waktu yang cukup lama bermain disana daripada membaca buku. Ditambah lagi dengan semakin berkembangnya jaman yang membuat semua hal menjadi instant sehingga remaja menjadi malas membaca buku dan lebih memilih mencari informasi dari internet, padahal banyak sekali informasi dari internet yang kurang jelas rujukannya. Hal ini berdampak pada turunnya kemampuan menghasilkan gagasan-gagasan baru dan menguraikan masalah secara rinci serta sistematik karna remaja sekarang beranggapan bahwa setiap permasalah sudah terdapat solusinya di internet.

Sedangkan pengamatan peneliti secara khusus pada pembelajaran ekstrakurikuler pada kelompok ilmiah remaja (KIR) di SMA Negeri 11 Luwu Utara pada tanggal 08 Februari 2021 menunjukkan bahwa siswa yang kebayakan siswa lebih memilih mencari meteri pembelajaran melalui hanphone ketimbang harus memcari materi di buku, di tambah lagi minat baca siswa semakin berkurang diakibatkan siswa memilih bermain game, maka dari itu guru di SMA Negeri 11 Luwu Utara, mengajak siswa untuk membiasakan membaca buku diwaktu isterahat dan di bantu oleh kelompok ilmiah remaja (KIR). (08 Februari 2021).

Berdasarkan pertimbangan di atas, maka penulis sangat tertarik untuk melaksanakan penelitian ini di karnakan masi bayaknya siswa yang kurang tertarik dengan budaya baca di karnakan pengaruh perkembangan saman dengan mengunakan internet yang membuat semakin mudah mencari materi. Maka peneliti tertarik meneliti masalah tentang "Konstruksi Budaya Literasi dalam Pembelajaran Ekstrakurikuler (Studi Pada Kelompok IImiah Remaja di SMA Negeri 11 Luwu Utara)".

\section{METODE PENELITIAN}

Jenis penelitian yang digunakan oleh peneliti adalah penelitian kualitatif deskriptif. Kualitatif adalah penelitian yang bermaksud untuk memenuhi fenomena tentang yang dialami subjek peneliti. Deskriptif adalah berupa kata-kata, dan gambar. Penelitian kualitatif deskriptif yang menguraikan fakta mengenai Konstruksi budaya literasi dalam pembelajaran ekstrakurikuler (studi pada kelompok ilmiah remaja di SMA Negeri 11 Luwu Utara). Keadaan dan situasi yang akan digambarkan dalam penelitian ini adalah bagaimana budaya literasi yang terdapat dalam pembelajaran ekstrakurikuler, bagaimana konstruksi budaya literasi dalam pembelajaran ekstrakurikuler pada kelompok ilmiah remaja dan faktor apakah yang menghambat konstruksi budaya literasi dalam pembelajaran ekstrakurikuler. 
Emzir, (2011:3) "Jenis penelitian kualitatif tipe deskriptif adalah data yang dikumpulkan lebih mengambil bentuk kata-kata atau gambar dari pada angka-angka". Hasil penelitian tertulis berisi kutipan-kutipan dari data untuk mengilustrasikan dan menyediakan bukti prestasi.

Creswell (2017:4) menjelaskan bahwa penelitian kualitatif (qualitative research) merupakan metode-metode untuk mengeksplorasi dan memahami makna yang oleh sejumlah individu atau sekelompok orang dianggap berasal dari masalah sosial atau kemanusiaan. Proses penelitian kualitatif ini melibatkan upaya-upaya penting, seperti mengajukan pertanyaan-pertanyaan dan prosedur-prosedur, mengumpulkan data yang spesifik dari para partisipan, menganalisis data dan menafsirkan makna data. Sehingga peneliti dapat mengeksplorasi dan mengumpulkan data tentang Konstruksi budaya literasi dalam pembelajaran ekstrakurikuler.

Metode deskriptif ini ialah metode yang menuturkan dan menafsirkan data yang ada, misalnya tentang situasi yang dialami, suatu hubungan, suatu proses yang sedang berlangsung, kelainan yang sedang muncul, kecenderungan yang nampak, pertentangan yang meruncing, dan sebagainya. Tujuan utama penelitian kualitatif adalah untuk memahami fenomena atau gejala sosial yang terjadi di SMA Negeri 11 Luwu Utara.

Pendekatan penelitian yang digunakan adalah pendekatan fenomenologi dimana dengan Studi fenomenologi mencoba mencari arti dari kebiasaan seseorang. Peneliti menghimpun data berkenaan dengan konsep, pendapat, pendirian sikap, penilaian, dan pemberian makna terhadap situasi atau pengalaman dalam kehidupan. Tujuan dari penelitian fenomenologis adalah mencari atau menemukan makna dari hal-hal yang esensial atau mendasar dari pengalaman hidup tersebut, penelitian dilakukan melalui wawancara mendalam yang lama dengan partisipan. Sehingga peneliti dapat mengkaji, memperdalam peristiwa tentang Kontribusi Organisasi Persit Dalam Pemberdayaan Masyarakat di Desa Pucangan Kecamatan kartasura Kabupaten Sukoharjo.

\section{HASIL PENELITIAN DAN PEMBAHASAN}

SMA Negeri 11 Luwu Utara adalah sekolah yang berada di JL. Dg. Mangatta Desa Tolada Kecamatan Malangke Kabupaten Luwu Utara, SMA Negeri 11 Luwu Utara merupakan sekolah Negeri yang berdiri pada tanggal 25 Juli 2006. Sejak berdirinya SMA Negeri 11 Luwu Utara pertama kali dibawah pimpinan Bapak Kepala sekolah pertama yaitu Bapak Ibrahim Nasir, S.Pd, yang menjabat dari tahun 2006 - 2012 beliau membangun SMA Negeri 11 Luwu Utara sehingga dapat setara dengan sekolah-sekolah yang ada di Kabupaten Luwu Utara lainnya.

SMA Negeri 11 Luwu Utara yang memiliki 24 (dua puluh empat) ruangan yang terdiri dari 17 ruang kelas, 3 laboratorium komputer dan IPA, satu ruang kantor, perpustakaan, ruang dan guru ruang osis, dengan begitu SMA Negeri 11 Luwu Utara memiliki potensi untuk bisa menjadi sekolah unggulan di masa yang akan datang.

Dalam penelitian ini sebagaimana diuraikan hasil penelitian dan pembahasan mengenai Konstribusi budaya literasi dalam pembelajaran ekstrakurikuler (studi pada kelompok ilmiah remaja di SMA Negeri 11 Luwu Utara) dilakukan dengan menganalisis data secara deskriptif, berdasarakan hasil wawancara yang telah dilakukan peneliti dengan mengajukan beberapa pertanyaan kepada informan kepala sekolah, guru, pustakawan dan juga beberapa siswa SMA Negeri 11 Luwu Utara. Adapun hasil penelitian yang dilakukan peneliti yaitu berdasarkan observasi, wawancara dan dokumentasi dalam proses pengumpulan data, setelah tahap pengumpulan data dilakukan kemudian peneliti melanjutkan pada tahap pengelolaan data yang selanjutnya dilakukan dengan menganalisis data secara deskripitif, tentang Konstribusi budaya literasi dalam pembelajaran ekstrakurikuler (studi pada kelompok ilmiah remaja di SMA Negeri 11 Luwu Utara). 


\section{Budaya Literasi Dalam Pembelajaran Ekstrakurikuler di SMA Negeri 11 Luwu Utara}

Menurut saya saat ini Pada dasarnya kegiatan ekstrakurikuler pengembangan diri atau bakat siswa di dunia sekolah ditujukan untuk menggali dan memotivasi siswa dalam bidang karya tulis ilmiah. Oleh sebab itu, kegiatan ekstrakurikuler harus disesuaikan dengan hobi maupun kondisi siswa. Sedangkan tujuan kegiatan ekstrakurikuler adalah untuk membantu dan meningkatkan bakat juga potensi siswa dalam menulis ilmiah dan membudayakan siswa untuk mau membaca buku. Sehingga kegiatan ekstrakurikuler kelompok ilmiah remaja dapat meningkatkan kemampuan berfikir ilmiah dan menuangkannya dalam sebuah tulisan ilmiah.

Menurut saya budaya literasi yang di terapak di SMA Negeri 11 Luwu utara mulai jelas dirasakan oleh semua siswa dan kegiatan ekstrakurikuler kelompok ilmiah remaja (KIR) sebagai tempat atau wadah siswa untuk bisa menuangkat bakatnya di bidang penulisan karya ilmiah maupun penulisan cerita pendek yang sering di adakan lomba tingkat sekolah.

Budaya Literasi dapat diartikan sebagai kemampuan mengakses, memahami, dan mengunakan sesuatu secara cerdas melalui berbagai aktivitas antara lain membaca, melihat, menyimak, menulis atau berbicara. Sedangkan menurut A.Chaedar (2012 : 160) secara sederhana, literasi dapat diartikan sebagai sebuah kemampuan membaca dan menulis. Sedangkan dalam arti luas kita mengenalnya dengan melek aksara atau huruf sehingga keberaksaraan bukan lagi bermaknaan tunggal, melainkan menggandung beberapa arti. Ada macam-macam keberaksaraan atau literasi, misalnya literasi membaca, literasi komputer, literasi virtual, literasi matematikan dan sebagainya.

Beberapa pendapat tersebut dapat disimpulkan bahwa budaya literasi disekolah dapat diartikan sebagai aktivitas literasi antara lain dengan adanya berbagai aktifitas yang sudah diterapkan disekolah dengan mengumpulkan jurnal harian siswa dan ada tagihan lisan dan tulisan yang digunakan sebagai penilaian non akademik. Menyediakan pojok literasi di perpustakaan, taman, atau lokasi manapun yang nyaman di lingkungan sekolah. Sedangkan kegiatan ekstrakurikuler adalah kegiatan pendidikan di luar mata pelajaran dan pelayanan konseling untuk membantu pengembangan siswa sesuai dengan kebutuhan, potensi, bakat, dan minat (interest) mereka melalui kegiatan yang secara khusus diselenggarakan oleh pendidik atau tenaga kependidikan yang berkemampuan dan berkewenangan di sekolah atau madrasah. Dalam juknis penyusunan program pengembangan diri melalui kegiatan ekstrakurikuler di SMA yang diterbitkan oleh direktorat pembinaan SMA tahun 2010, dijelaskan bahwa Kegiatan ekstrakurikuler merupakan wadah yang disediakan oleh satuan pendidikan untuk menyalurkan minat, bakat, hobi, kepribadian dan kreativitas peserta didik yang dapat dijadikan sebagai alat untuk mendeteksi talenta peserta didik.

kegiatan ekstrakurikuler bertujuan untuk mengembangkan salah satu bidang pelajaran yang diminati oleh sekelompok siswa, misalnya membaca buku, olahraga, kesenian, berbagai macam keterampilan dan kepramukaan. Menurut Rusman (2011:20) tujuan kegiatan ekstrakurikuler adalah memberikan pengalaman yang sesuai dengan hobi, bakat, minat dan kemampuan peserta didik. Menurut Mulyono (2010: 188) fungsi kegiatan ekstrakurikuler adalah a) Meningkatkan kemampuan peserta didik sebagai anggota masyarakat dalam mengadakan hubungan timbal balik dengan lingkunganm sosial, budaya dan alam semesta. b) Menyalurkan dan mengembangkan potensi dan bakat peserta didik agar dapat menjadi manusia yang berkreativitas tinggi dan penuh dengan karya. c) Melatih sikap disiplin, kejururan, kepercayaan, dan tanggung jawab dalam melaksanakan tugas. d)

Mengembangkan etika dan akhlak yang mengintegrasikan hubungan dengan Tuhan, manusia, alam semesta bahkan diri sendiri. e) Mengembangkan sensitivitas peserta didik dalam melihat persoalan persoalan sosial-keagaman, sehingga menjadi insan yang proaktif terhadap permasalahan sosial-keagamaan. Hubungan Teori konstruksi sosial yang di kemukaka oleh Peter L Berger dan Luckman dengan hasil temuan yang dilakukan peneliti yaitu fenomena budaya literasi terhadap pembelajaran ekstrakurikuler kelompok ilmiah remaja (KIR) yang terjadi di sekolah SMA Negeri 11 Luwu Utara dengan kesinambungan kenyataan muncul dimana muncul suatu masalah, misalnya konstruksi sosial yang terjadi pada peserta didik dalam mengikuti kegiatan estrakurikuler kelompok IImiah remaja, kesinambungan terjadi ketika peserta didik memiliki pandangan berbeda pada lembaga bimbingan belajar non formal. Peserta didik di sisi lain memiliki pandangan positif 
pada lembaga bimbingan sehingga objektivasi terhadap lembaga bimbingan belajar bernilai positif begitupun sebaliknya. Dari hasil penelitian dapat di simpulkan bahwa pandangan siswa mengenai ekstrakurikuler kelompok ilmiah remaja sangat merespon dengan baik dan peserta didik banyak yang tertarik untuk bergabung dan dapat mengembangkan bakatnya sesuai dengan bidangnya.

Hubungan Teori sistem sosial yang di kemukaka oleh talcott parsont dengan hasil temuan yang dilakukan peneliti yaitu fenomena yang terjadi di sekolah yang saling berinteraksi satu sama lain agar dapat mengenal, toeri ini juga melihat dari fakta-fakta di lapangan bahwa siswa saling membutuhkan untuk menutupi kekurangannya. Dari hasil penelitian di atas dapat di simpulkan bahwa teori sistem memandang setiap fenomena mempunayai berbagai komponen saling berinteraksi satu sama lain agar dapat bertahan hidup. Teori ini mengajarkan petingnya saling berbagi antar siswa di sekolah yang hidup bersama.

Dari pendapat tersebut dapat disimpulkan bahwa tujuan dari kegiatan ekstrakurikuler adalah membentuk kepribadian siswa serta mengaktualisasikan dan mengembangkan potensi yang dimiliki oleh siswa agar siswa dapat mencapai prestasi yang sesuai dengan bakat dan minat.

\section{Konstruksi Budaya Literasi Dalam Pembelajaran Ekstrakurikuler Pada Kelompok IImiah Remaja (KIR) di SMA Negeri 11 Luwu Utara}

Implementasi budaya literasi yang di terapkan sekolah SMA Negeri 11 Luwu Utara jelas di rasakan oleh siswa, mulai semakin memadainya perpustakaan dengan koleksi buku yang semakin banyak, ruang yang di sediakan terawat dan taman baca yang tertata rapi membuat siswa tertarik untuk membaca buku.

Salah satu kegiatan ekstrakurikuler yang di bina di SMA Negeri 11 Luwu Utara ialah Kelompok IImiah Remaja (KIR) yang sangat erat hubungannya dengan pembelajaran ekstrakurikuler dikarnakan pembelajaran tambahan di luar sekolah di bina dan di bimbing di bawah naungan pembelajaran ekstrakurikuler. KIR adalah kelompok remaja yang melakukan serangkaian kegiatan yang menghasilkan suatu hasil yang disebut karya ilmiah. Karya ilmiah itu sendiri mempunyai arti sebagai suatu karya yang dihasilkan melalui cara berpikir yang menurut kaidah penalaran yang logis, sistematis, rasional dan ada koherensi antar bagian bagiannya. Sebagai suatu kegiatan ekstrakurikuler di tingkatan SLTP, SMU, SMK, Madrasah bahkan Pondok Pesantren, Kelompok IImiah Remaja (KIR) ini merupakan suatu organisasi yang sifatnya terbuka bagi para remaja yang ingin mengembangkan kreativitas, ilmu pengetahuan dan teknologi pada masa kini maupun masa mendatang.

Tujuan yang harus dicapai oleh anggota KIR secara individual adalah pengembangan sikap ilmiah,kejujuran dalam memecahkan gejala alam yang ditemui dengan kepekaan yang tinggi dengan metode yang sistematis, objektif, rasional dan berprosedur sehingga akan didapatkan kompetensi untuk mengembangkan diri dalam kehidupan.

Salah satu harapan peneliti terhadap kelompok ilmiah remaja (KIR) ialah kelompok ini terus membantu sekolah dalam segi prestasi serta membantu sekolah dalam mengembangkan budaya literasi dan mengajak siswa untuk bisa terus membaca di waktu isterahat serta siswa lain dapat mengikuti jejak siswa lain yang telah berprestasi.

Hubungan teori Peter L Berger dengan hasil penelitian dibagi menjadi tiga reality yaitu eksternalisasi, obyektivitas dan internalisasi. Eksternalisasi yaitu suatu usaha untuk pencurahan atau ekspresi manusia kedalam dunia, baik dalam kegiatan mental maupun fisik. Eksternalisasi merupakan hasil dari kreatifitas manusia untuk menciptakan suatu produk hasil dari pemikirannya yang berupaka karya tulis ilmiah yang di buat oleh kelompok ilmiah belajar yang menuangkan hasil kreasinya ke dalam sebuah tulisan. Sedangkan obyektivasi yaitu hasil yang dicapai, baik mental maupun fisik dari kegiatan eksternalisasi. Tahap yang di capai di sini adalah siswa harus mampu menciptakan suatu hasil dari pemikirannya yang dapat digunakan oleh orang lain, hasil pemikiran yang di maksud yaitu karya ilmiah yang di ciptakan oleh siswa yang tergabung dalam kegiatan ekstrakurikuler kelompok ilmiah remaja .Internalisasi yaitu proses ini lebih menerapkan. 
Jadi dapat disimpulkan bahwa teori Konstruksi sosial yang di kemukakan oleh Peter L Berger dengan hasil penelitian yang dilakukan peneliti adalah bagaimana seorang guru bisa mengajak siswa untuk mau membaca buku dan bisa membudayakannya di dalam lingkungan sekolah, serta kelompok ilmiah remaja (KIR) mampu mengajak siswa lain untuk membaca.

Hubungan teori Fungsional Struktural dengan hasil temuan yaitu hasil yang didapatkan atau input dari hasil budaya literasi yang dilakukan oleh sekolah SMA Negeri 11 Luwu Utara disini sangat terbukti dengan peningkatan minat baca siswa dan kelompok ilmiah remaja yang bisa menorehkan prestasi dengan mengikuti lomba penulisan karya ilmiah dan di harapkan kedepannya siswa lebih tertarik lagi untuk membaca buku.

\section{Faktor Yang Menghambat Konstruksi Budaya Litersi Dalam Pembelajaran Ekstrakurikuler di SMA Negeri 11 Luwu Utara}

Hasil penelitian yang dilakukan oleh peneliti di dapatkan data bahwa faktor yang menjadi penghambat siswa untuk membudayakan membaca dikarnakan siswa masi kurang tertarik membaca buku di tambah lagi dengan adanya pandemic covid membuat siswa di rumahkan dan tidak diadakan tatap muka untuk mencegah penularan virus menjadikan siswa mengabaikan pembelajaran yang di berikan oleh guru, mereka lebih mementingkan bermain game maupun bekerja membantu orang tuanya.

Faktor kurangnya minat baca siswa di sebabkan pergaulan yang semakin hari semakin bebas yang mengakibatnya turunya moral seorang siswa, dilain sisi kurangnya pengawasan guru maupun orang tua siswa mengakibatkan siswa tidak belajar di tambahkan lagi faktor tidak tertariknya siswa untuk belajar dan membaca di sebabkan siswa lebih memilih bermain game di banding membaca buku yang di berikan kepada siswa.

Selain dari faktor di atas kondisi pandemik saat ini juga menjadi salah satu faktor terbesar yang mengakibatkan kurangnya minat baca siswa, situasi ini menjadi tambah sulit bagi guru untuk bisa mengontrol siswa yang di rumahkan. Pembelajaran daring yang dilakukan oleh sekolah menambah semakin sulitnya guru untuk mengontrol siswa agar tetap belajar dan membaca buku pembelajaran.

Maka dari itu sekolah mengupanyakan agar di adakan pertemuan seminggu sekali agar siswa kesekolah untuk mengambil buku pelajaran maupun buku bacaan untuk di pelajari di rumahnya masing-masing dan mengajak kelompok ilmiah remaja untuk membantu guru untuk mengigatkan kesiswa lain untuk tetap membaca buku di manapun tempatnya.

Salah satu usaha yang dilakukan untuk membiasakan siswa membaca di SMA Negeri 11 Luwu Utara adalah melakukan gerakan literasi (membaca dan menulis). Gerakan ini dilakukan oleh guru dan siswa. Bagi guru utamanya pengajar Bahasa Indonesia, hal ini menjadi lebih mudah. Beberapa pendidik memilih bahan bacaan (cerpen yang menarik) bagi siswa untuk dijadikan bahan ajar sehingga siswa tertantang untuk membaca dan menulis sesuai contoh pembelajaran. Pengajar memilih cerpen karya siswa atau guru yang merupakan hasil pemenang Lomba. Apabila Sang guru memiliki hasil karya berupa cerpen sebaiknya tulisan Sang guru diperkenalkan kepada siswa untuk dibaca.

Dari hasil pembahasan di atas peneliti mengaitkan penelitian dengan teori Fungsional Strutural yang melihat dari hasil upanya sekolah maupun guru untuk mengajak siswa untuk mau tetap membaca buku dimanapun tempatnya.

\section{KESIMPULAN}

Berdasarkan hasil pembahasan penelitian diperoleh kesimpulan sebagai berikut: 1 . Budaya Literasi yang di terapkan di SMA Negeri 11 Luwu Utara saat ini mulai bejalan dengan baik dengan banyaknya siswa yang tertarik untuk membaca buku di tambah lagi di bentuknya kegiatan ekstrakurikuler kelompok ilmiah remaja (KIR) yang menambah semangat siswa untuk terus membaca karna kelompok ini membina siswa untuk dapat berkarya melalui sebuah karya tulis 2 . Konstruksi budaya literasi yang di bagun di SMA Negeri 11 Luwu Utara saat ini mulai berjalan dengan baik, dengan di bagunnya taman baca serta sudut baca yang di sediakan sekolah menambah tempat 
maupun ruang kepada siswa untuk menyalurkan bakatnya dengan membaca buku. 3. Faktor yang mempengaruhi yang menghambat konstruksi budaya literasi dalam pembelajaran ekstrakurikuler di SMA Negeri 11 Luwu Utara. ialah kurangnya minat baca siswa yang di sebabkan kejenuhan siswa untuk membaca buku yang terlalu tebal serta kurangnya minat baca di akibatkan pengaruh game online, serta adanya dampak pandemik yang membuat siswa di rumahkan yang mengakibatkan guru mengajar daring yang menyebabkan siswa tidak ada yang mengotrol pembelajarannya.

Adapaun saran dalam penelitian ini adalah sebagai berikut: 1. kepada kepala sekolah maupun guru serta Pembina kelompok ilmiah remaja (KIR), hendaklah mengupayaan adanya sosialisasi kepada siswa untuk membudayakan literasi (membaca), serta memperlengkap buku bacaan yang ada di perpustakaan sekolah serta mengajak kelompok ilmiah remaja untuk membantu sekolah untuk mensosialisasikan budaya literasi di SMA Negeri 11 Luwu Utara. 2. kepada siswa, peneliti mengharapakan untuk bisa meluangkan waktunya untuk bisa membaca buku baik di sekolah maupun di luar sekolah, serta kepada kelompok ilmiah remaja untuk bisa meningkatkan kemampuan menulisnya. 3. kepada penelitian selanjutnya disarankan untuk dapat memperbanyak jumlah subjek agar sebaran data yang diperoleh akan semakin merata dan mampu mewakili populasi normal. Selain itu, peneliti selanjutnya juga perlu mengadministrasikan dan mengawasi secara langsung pada saat pengisian skala agar terhindar dari berbagai bias yang mungkin terjadi. Peneliti juga menyarankan pada penelitian selanjutnya untuk memperluas kajian tentang konstruksi budaya literasi dalam pembelajaran kelompok ilmiah remaja dengan mencari faktor-faktor yang memengaruhi minat baca siswa.

\section{DAFTAR PUSTAKA}

Abidin, Y. Mulyati, T. \& Yunansah, H. (2017). PEMBELAJARAN LITERASI:Strategi Meningkatkan Kemampuan Literasi Matematika, Sains, Membaca, Dan Menulis. Jakarta: Bumi Aksara

Creswell W, John. (2017). Research Design (Pendekatan Metode Kualitatif, Kuantitatif, dan Campuran. Yogyakarta: Pustaka Pelajar.

Direktorat Pembinaan SMA. (2010). Juknis Penyusunan Program Pengembangan Diri Melalui Kegiatan Ekstrakurikuler di SMA. Jakarta: Direktorat Pembinaan SMA.

Emsir. (2011). Metodologi Penulisan Kualitatif Analisis Data. Jakarta: Raja Grafindo Persada.

Keraf, Gorys. (2007). Argumentasi dan Narasi. Jakarta: PT Gramedia Pustaka.

Mulyono. (2010). Manajemen Administrasi dan Organisasi Pendidikan. Yogyakarta: Ar-Ruzz media.

Rusman. (2011). Manajemen Kurikulum. Jakarta: Rajawali Press.

Susilowarno RG. (2003). "Kelompok Ilmiah Remaja" (Petunjuk Membimbing dan Meneliti Bagi Remaja). Jakarta: Grasindo.

Wendra, I Wayan. (2016). Penulisan Karya Ilmiah (Buku Ajar). Singaraja: Universitas Pendidikan Ganesha.

Wiedarti, dkk. (2016). Desain Induk Gerakan Literasi Sekolah. Jakarta: Direktorat Jenderal Pendidikan Dasar dan Menengah Kementerian Pendidikan dan Kebudayaan. 